\title{
The Position of Human Being in the Universe according to Islam
}

\author{
Recep Dogan \\ Charles Sturt University, Centre for Islamic Sciences \& Civilization (CISAC), Faculty of Arts, Charles Sturt University \\ *Corresponding Author: rdogan@csu.edu.au
}

Copyright (C) 2013 Horizon Research Publishing All rights reserved.

\begin{abstract}
The purpose of this study is to explore the place of humankind amidst the entire creation according to the Islamic perspective. We have examined the critical areas of knowledge on human beings. Focusing on the empirical, emotional and rational sides of human beings; we have discussed the mechanisms that accentuate a human soul, and the place of human reason in this mechanism. Pointing to the arguments of whether human beings are born in a neutral or laden with meanings, we have been reminded of human's venture of giving meanings to things and beings in the universe. Referring to the vicegerency of human beings on earth, we have indicated how human beings have contributed to the maturation process in the universe with all the talents, blessings and faculties they are given such as speech, rhetoric and intellect.
\end{abstract}

Keywords The Identity, Humankind, Position of Human Being in the Universe, The Essence of Human, Natural Disposition

\section{Introduction}

Human beings endeavor to acquire necessary skills by virtue of their innate nature. Daily tasks and routines such as walking, acquiring language during the early years of their lives with their God-given natural abilities, talents and genetic endowments are but some of many examples. Humans, by nature also strive to acquire a variety of skills and abilities throughout their life span. In order to define the identity and nature of human kind properly and to be able to grasp his/her true essence, these two aspects of life should be scrutinized and handled separately. Whilst one aspect is related to the question "What is a human being in his or her essence?" the other fundamental question that needs to be raised is "Who has he or she become?" Consequently, these two aspects are concerned with the formation and development of a human being, analyzing what he/she was at birth whilst also focusing on what he/she has become through actions, preferences and achievements.
The question of "who" relates to human beings as a unique, distinguished entity. This can be answered by defining sentimental, rational, social and political conducts of human kind and also by defining their physical and intellectual works. As a result, the identity of human being is constructed progressively in a dynamic way. It is not acquired at birth, but rather is gained with individual and social experiences and achievements. As human beings interact with one another they develop relationships with the society in which they live as well as with their Lord Creator. These relationships will in turn contribute to construe their identity, actualize their potential, form their character and give them individual worth. Individuals can attain a sound identity by recognizing these relationships and also by being aware of their inherent potential.

The unique human identity is a source of honor for humankind and it is shaped with internal and external factors. In a social institution, human kind builds up their own identity and gets more freedom by establishing his unique personality. In other words, people gain their identity through their relationships in the environment and the society in which they live.

The true human identity does not particularly enslave the individual to the surrounding society, politics, race or the current culture; rather it lets one evaluate and criticize all this, and thereby exceed their boundaries and create a new culture. It is for this reason that the identity of humans can be addressed with the efforts they have exerted and the values they have gained. If human values are given at birth then they are related to their natural essence. Under these circumstances, human being does not construe those values but they are only carrier of them.

What a human being is in regard to his/her conduct can be answered with the example of an artist who designs things according to a certain plan and exerts an effort for the result.[1]Aristotle holds that every art, knowledge, or movement is a step towards a good goal.[2]If one sees his/her own life as his/her capital, he/she would express the goodness with his work regardless of his/her field of work. Mankind generally strives to actualize an intended result, with the focus of their work being themselves, in light of the 
environment in which they operate. A human being, in their life time is forever undergoing change, learns to adapt to change and develops themselves. It is this human ability and experience that separates them from other created beings.

\section{Methodology}

The methodology used will be a systematic review of literature and look at the books which cover the position and importance of man according to different views and within specific perspectives. While preparing the essay, both modern and classical works have been used. The different approaches on human value in the universe such as Christian, Islamic and Modern perspectives have been reviewed, cited, and discussed with their positive and negative observations. The comparison between the views provided an opportunity to reach a conclusion which is stated at the end of this work.

\section{The Essence and Origin of Human Being}

The ideas about the origin of mankind on earth are the basis for every worldview because the issue of the origin of human being on earth is very important in order to be able to answer the questions "who" and "what" he/she really is. Modern science attempts to explain the origin of mankind within the theory of evolution and sees the human as a trivial part of "nature." Conversely, religion accepts human beings as the best art of creation, because He created man with His own hands and breathed the spirit into their bodies. The journey of mankind starts on earth after having being temporarily driven out of Paradise. It is here, on earth that God wills for them the mission and opportunity of completing their perfection in order to regain paradise. In other words, by exiling mankind to earth, God did not punish them; rather He gave them another temporal opportunity to achieve and regain Paradise again by fulfilling their mission on earth as representatives, and as vicegerents of God Almighty.

The creation of mankind brought new color to the art of creation and they are created to bring the tree of creation to completion. Until the creation of mankind, other beings were categorized as either physical or metaphysical. However, humankind was created as connection between both of these physical and metaphysical spheres and was destined to strike a balance between them. [3] God endowed them with great capacity to achieve good things as well as the ability to use it in the destructively and destroy things. The question of use and abuse on this earthly plane was to be mankind's first and foremost challenge on a historical time line. In this regard, endowed with the options of free choice and discretion, mankind found themselves forever faced with two options: to achieve Paradise through good righteous holistic living and deeds or end up in Hell forever chastised and condemned.
It now becomes clear that this capacity of mankind given his/her own free will, choices and decision making -all come with great responsibility and accountability.

\subsection{Islamic View on the Origin of Humankind}

Humankind is created in the best form of creation with both inner and outer beauty and potentials. Despite his/ her relative, insignificant minuscule special occupation of earth, his/her value is equal to the entire universe, because God exclusively assigned him/her as His vicegerent on earth. The Qur'an mentions human as the vicegerent, or representative of God:

Remember (when) your Lord said to the angels: "I am setting on the earth a vicegerent." The angels asked: "Will you set therein one who will cause disorder and corruption on it and shed blood, while we glorify You with Your praise (proclaim that You are absolutely free from any defect and that all praise belongs to You exclusively,) and declare that You alone are all-holy and to be worshipped as God and Lord." He said: "Surely I know what you do not know." Having brought him into existence, God) taught Adam the names, all of them. Then (in order to clarify the supremacy of humankind and the wisdom in their being created and made vicegerent on the earth), He presented them (the things and beings, whose names had been taught to Adam, with their names) to the angels, and said, "Now tell Me the names of these, if you are truthful (in your praising, worshipping, and sanctifying Me as My being God and Lord deserves)." In acknowledgement of their imperfection, and their perception of the truth of the matter, the angels) said: "All-Glorified You are (in that You are absolutely above having any defect and doing anything meaningless, and Yours are all the attributes of perfection). We have no knowledge save what You have taught us. Surely You are the All-Knowing, the All-Wise." In order to demonstrate the superiority of humankind more clearly, God) said: "O Adam, inform them of these things and beings with their names." When he (Adam) informed them with their names, He said (to the angels), "Did I not tell you that I know the unseen of the heavens and the earth, and I know all that you reveal and all that you have been concealing?" And (remember) when We said to the angels: "Prostrate before Adam!" They all prostrated, but Iblis did not; he refused, and grew arrogant, and displayed himself as an unbeliever.[4]

Angels were already aware that humankind was prone to causing disorder, corruption, and bloodshed through the Protected Tablet (lawb mabfüz) [5] and asked God the question in the verse above, in order to understand the Divine Wisdom in setting humankind on the earth as vicegerents. In the face of disgusting scenes in terms of corruption in human values, they wondered: "what is the wisdom in God's creating and allowing such things?" [6]The angels did not know that among the human species the prophets, saints, scholars, scientists, wise and ethical people will appear and contribute to effecting justice and harmony on earth. In the absence of these good agents of change and advancement it 
would otherwise have been pointless to assign mankind as the vicegerent of God on earth.

Endowing him/her with intuitive knowledge and skills, God has granted authority to mankind to intervene, create and control things to some extent-in the overall plan of his/her sojourn on earth. Armed with this endowment, mankind would gain sovereignty in their own realm on earth and also act freely in the universe, on behalf of God. With this authority humankind judges, makes decisions and takes action in the name of God.[7] One of the reasons for the angels asking God the question under discussion was that human's overall physical nature also embodied seeds of evil along with the potential for good.

Moreover human's unique mechanisms of conscience weaved of the heart, will-power, power of intellect, perception, and consciousness will also be accompanied with a carnal soul which would embody such feelings as hatred, lust, anger, and greed. [8]God's response to their question connotes deep wisdom and indicates the profound dimensions of man's creation.

\subsection{Superiority of Humankind: Language}

Being uniquely different from other creatures, human beings have the ability to speak a language where meanings can be drawn with the use of words. As mentioned above, God endowed this capacity to mankind and this indicates that the teachings of God are related to knowledge. The words or names convey close meaning about the knowledge of reality and of God. They also make it scientific endeavors and advancements achievable; otherwise without the means of language, mankind cannot acquire knowledge or convey it onto the next generations. Moreover, language gives humankind an opportunity to imagine things without needing their actual presence and an ability to talk to God for their needs.

Humankind likes to use symbols and attach meanings to them. The curiosity in their nature makes them investigate the nature around them and learn the symbols of the natural world. With this activity, they are not only limited within their nature but they also discover the meanings of the objects in the universe. For this reason, mankind has the ability to use language and attach meanings to words and use words to understand and describe their subjects. With these characteristics, language is a divine gift exclusive to human beings. [9]Teaching names to Adam includes the capacity of naming the objects in nature and the related verses summarize the whole Islamic Theology, Anthropology and Cosmology.[10] Adam is introduced as a Prophet in the Qur'ān rather than as a sinner, and this is the reason why God commanded angels to prostrate before him. These verses also explain why everything on earth has been subjugated to human beings. This point clarifies that sovereignty in the universe is not only related to human's capacity for knowledge but also their value in the sight of God. One aspect of mankind's value is using language in a meaningful way.
Words are important to comprehend abstract meanings.[11] While the intellect evaluates symbols, figures and words to obtain meaning; on the other side, intellect itself are shaped with the experiences and symbols built within the course of history. In other words, intellect functions in individuals as how history functions for the societies. [12]The thoughts of the past shape the future and with this perspective, we try to understand the nature and identity of humankind.[13] It is no surprise of history thus, that the very first science Adam -here representing all of future humankind-was taught by God Almighty -was the language to speak, and name all things created around him. Language is full of meaning and symbols. Mankind does not become a foreigner merelyby not understanding the language in a certain place, but rather by not contributing to the establishment of the language in that place.[14] For this reason, Divine teaching of the names was not only for Adam, but rather for all humankind.

\subsection{The Relationship between Language and Sciences}

What was taught to Adam, the forefather of humanity, were seeds of comprehensive knowledge or sciences, which would be taught to humanity in its worldly life, just as every race and blood group was included in Adam's loins. [15]People who came after Adam have progressed these seeds and established sciences and disciplines in many different areas. The teaching of the names to Adam might have happened in the same way that God Almighty implanted or sowed the seeds of fundamental knowledge of all things in his spirit. Thus, on a historical datum line, any particular thing just came into being, happened or evolved in its time, every time as the divine plan decreed. It could also be that God had enabled Adam to be aware of both the names and the things to be called by the names through the feelings of neediness intrinsic to humanity and the desire and capacity of learning that He ingrained in its very being.[16]

The capacity of language and using it is pivotal for the progress of mankind.[17] Carrying out the responsibility of vicegerency on earth depends on a language. One of the qualities of Adam which angels are deprived of was language and with this ability Adam built a new world which is full of meanings. Adam established his sovereignty over things through the means of language. Thinking deeply and having a broad horizon in thought is related to having comprehensive knowledge in language. Many profound scholars could not be understood entirely by later generations because of their language and depth of thought.[18]

\subsection{The Importance of Intellect for Human Identity}

As mentioned earlier human beings can act according to their intellect and rationality but natural instincts can also be the basis for their conduct. However, they are aware of all of these motives and this awareness makes them unique. With growth and development, mankind recognizes and identifies 
their ego, identity, capacity and weaknesses and with their intellect they develop themselves to an unlimited extent.[19] Human's intellect symbolizes their freedom and transcendence. German thinker Goethe speaks of the intellect as the free and independent capacity of mankind.[20]

Intellect is the foundation of morality and good character, because it is through the intellect that one attains awareness of his/her relationships with the environment and those around him/her. However, besides intellect natural instincts also have an effect on the conduct and behavior of individuals. The intellect and natural instincts might come into conflict, because natural desires are not given to human in balance and harmony. The duty of controlling natural desires and disciplining them is left to the human free will. If mankind would act according to his natural instincts only, he/she would cease to continue to exist in a lofty human dimension.[21]

In the past, theorists, philosophers and thinkers have already attempted to put into perspective human's purpose on earth and identifying the makings of the human conscience. Nietzsche deems nature as a field for racing between free wills; ego is in the body and there is nothing beyond this, soil is also a word in the body and intellect is the highest wisdom in human nature. [22] For him, the ideas and thoughts take place in human intellect in a cause and effect relationship and this is related to human perception.[23] Engels holds that the intellect and thoughts may be deemed supernatural but indeed they are just products of the brain and the intellect itself is the highest materialistic product. [24]In this view, mankind is not different from any other animal or object in nature. This view denies all the spiritual and metaphysical sides of mankind and evaluates it as a product of nature.

Alternately according to Islamic thought, God created mankind without giving him the perfection of abilities and capacities. Moreover, human beings have the potential, ability and capacity to be perfect by employing the free will to its highest and fullest potential. In this regard free will can be actualized by using it against the natural instincts. [25] Should free will be used succumbing to animalistic, carnal desires and is isolated from intellect, it will harm the individual. Indeed, natural instincts are the motivating power for man if they are utilized in balance and harmony. It is for these reasons that Islam does not really see natural instincts as bad or blameworthy, but it blames irrational conduct and desires. If natural desires are disciplined with intellect and free will, then they become an asset for mankind.

\section{Human Being with Natural and Achieved Capacity}

It is possible to define human beings according to their natural and achieved capacity. The physical side may have some commonality with other living beings in nature. Conversely the metaphysical side of mankind, such as the feelings of justice, belief, intuition, morality, love, emotion and empathy etc. can only be explained from the non-physical and spiritual perspective. Therefore in this dimension of mankind; he/she emulates and tries to imitate as far possible, the qualities and character of God (Akhlaq Allah). Having certain intentions and goals in his/her conduct, the individual carries out his/her responsibilities, and this attribute indicates the transcendent aspect of human being.[26]

The composition of mankind with his/her biologic, intellectual, spiritual and life values are very complex and intricate. Separating human's physical side from their meta physical one and accepting one of them as their true essence can never be free from fault. Father of Psychology and Psychiatry Sigmond Freud tried to explain this complex entity from an exclusively physiological and biological point of view. Not being a spiritualist or religionist however, he failed to clarify the point of how the metaphysical side of mankind came about.[27]

\subsection{Islamic View}

In Islamic thought, the human being is so valuable and unique that each individual is equal to the entire universe in value. Evaluating them by making generalizations cannot really define man and explain his intricate nature and essence. Interestingly, modern Psychology conducts research on individuals and generalizes findings to all human kind. [28]This view is as flawed and should be changed and as individuals should be evaluated according to their own experiences, inclinations, capacities and so on.

Islam views the overall make up of mankind as a whole and does not separate one aspect from the other. Despite the presence of carnal desires and uncontrolled feelings, they also have the capacity, with their intellect and free will to control, regulate and utilize these feelings in the right way. Mankind can determine what the right action is and he can produce right conduct or behaviors. Evil takes place when human beings fail to control their feelings and can become slaves to their instincts. The Qur'an explains this as a physiological disorder; "In the very center of their hearts is a sickness..."[29] When the intention is bad or evil, the conduct will be evil as well. Putting evil intention into action more than often results in committing more evil which creates a vicious cycle, whereby evil thoughts and intentions generate many other evil thoughts and deeds.[30]

The intellect, consciousness, and communication skills are important to define human beings from the view point of Anthropology. However, these characteristics and intellectual abilities have a religious aspect as well. Philosophically it can be identified and categorized through the relationship of individuals with God, themselves, with other people, and those around them. The metaphysical abilities or qualities of man are the essence of human identity and they exist independently. This capacity makes a human being unique and a vicegerent, or representative, of God on earth. Mankind finds necessary motivations in their 
metaphysical selves to be able to act on behalf of God. For example, the concept of justice is independent and it has existed before Adam was created. When mankind finds this concept in his/her nature he/she understands that it is indeed, coming from the All-Just One. In this regard, providing justice on earth represents one of the attributes of God in the human dimension. I would like to mention two verses from the Qur'an to elaborate the two sides of man. The first one is as follows:

"The human selfhood and that (All-Knowing, All-Powerful, and All-Wise One) Who has formed it to perfection; and Who has inspired it with the conscience of what is wrong and bad for it and what is right and good for it."[31]

Here, the essential parts in human nature or in human selfhood are mentioned. The innate feeling of justice, belief, curiosity, and so on is present at birth and man has no part in attaining these feelings. These values or essences exist independently as they do not require human existence to exist. These values get their existence from God, because their source is the attributes of God. With these essential values, mankind has a feeling and insight for what is good and what is bad without a further need for reasoning. In the second verse below, God Almighty explains the achieved part in the nature of man:

"God brought you forth from the wombs of your mothers when you knew nothing, and endowed you with hearing and eyes and hearts, that you may give thanks"[32]

This verse indicates that human beings start to learn after birth and God has endowed them with the necessary skills and capacity for education. The values or the products which mankind can achieve after his/her birth are physical, thus opposite to his/her metaphysical side. Qur'ān names the achievements after birth as "thing." These physical products are generally nourished with metaphysical values unless the individual completely destroys his/her spiritual side. When the physical component prevails in human nature, the metaphysical side cannot be effective on human behavior. These types of human beings are criticized by God in the Qur'ān because they lose human dignity and honor by following their carnal desires and lowly instincts and ignoring the universal values. Moreover, they waste all their capacity in wrong ways instead of producing good conduct. The essence of a human being is to create good values and it is also the capacity to use the free will.

\section{The Discussions over the Value of Human Beings}

A worldview is the effective cause for evaluating things and interpreting them. Our worldview determines which factors are important in our experiences, which one is eternal, which one is temporal and which one happens in relation to cause and effect. Our worldview also helps us to understand what the ultimate source is and to find the essential value in nature.[33]
Every human being has a unique identity and ego. This ego is a vehicle in the activities of the intellect. According to Aristotle, the knowledge of ego cannot be objective about itself. If intellect takes part in knowledge, it cannot define itself objectively because in this case it is the one which gets the knowledge and also the subject at the same time.[34]

\subsection{Modern View}

In order to understand the modern view about human beings, the medieval perspective of mankind should be mentioned. There are three key points in Medieval Christian perspective: 1) The world is created by God and $\mathrm{He}$ is the greatest power in the universe, 2) Mankind has a unique position among other beings, God created man in His own image, 3) The life in the world is not final, rather it is only a beginning.[37]The modern view denies all of these notions. With the Darwinian Theory, mankind is deemed as part of nature and the notion of deity is denied. As a result humankind lost their significance and thus their unique position in the universe. For this view, mankind is not a vicegerent on earth and thus he is not created in the image of God. Mankind is classified as an idealist, naturalist, rationalist or romantic in modern view.[38]

The postmodern view emphasizes on self-adequacy. They hold that it is permissible to benefit from the notion of revelation, but religion is never considered as the ultimate criteria to prove something true, because only scientific evidences are sufficient and convincing for them. In this view, mankind is part of nature and belongs to this world. This view rejects anthropocentrism approach.[39]This view does not debase other beings or objects in nature while praising human beings; rather they accept nature as having independent value.[40]

\subsection{Islamic View}

Mankind has a great potential to be perfect and contribute to justice and harmony in society. Islam does not aim to transform the human being into an angel, because God created human beings different than angels and there is wisdom in this. Islam aims to help mankind actualize his/her potential and become a perfect human (Insan al-Kämil). The Prophet of Islam, Muhammad (pbuh) as well as other prophets in history is proposed to be role models in this regard, to be imitated and emulated. Islam recognizes denouncing the worldly pleasures to a certain extent but it never ignores life, health, intellect, social conduct, happiness and inclination to worldly pleasures. The notion of denouncing worldly pleasures in Islam- is striking the balance between carnal desires and moral values.

The Prophet lived as a human amongst human beings, produced the best exemplary human conduct and became the paragon of exemplary moral values in the human dimension. He never aimed to change the nature of human beings into angels; rather he recognized human nature and established Islam in a way which satisfies both the physical and 
metaphysical needs of individuals. He brought balance between religious life and daily routine and he removed the dualistic view; worldly and other worldly.

Significantly in Islam, religion and science are considered as two complementary sides of one reality whilst there exists no contradiction between the two as both emanate from the same source. On the contrary, the Qur'ān encourages people to think, to understand, to question, to criticize and to find the truth with their intellect. It also abhors and discourages blind imitation as it is against the dignity and honor of human beings. Islam encourages mankind to take the whole responsibility of vicegerency on his/her shoulders and offers full and complete life for them. Using their free will in the best way possible, mankind exerts effort, struggles and produces in this world and the reward comes accordingly. This notion determines their destiny.

Human life is established upon two main primary motives. While one is the inclination to happiness and power, the other is to exalt through moral values and continuously produce. Although the Bible blames physicality and human instincts and promotes the spirit only, the Qur'ān recognizes both sides of human nature. The perfection of mankind relies on struggling against negative feelings and utilizing them in a beneficial way, but not ignoring or getting rid of them completely. Disciplining the carnal desires and utilizing them to achieve something is related to the notion of a perfect, universal human being.

While Islam never entertains the idea of original sin, it promotes the rights, freedom, responsibility and free will of man. The notion of a perfect, universal man is important to understand the Islamic view of human worth and value. In this notion, human beings are not blindly submissive; they are actively using their intellect and freewill whilst also receiving divine guidance to complete the journey to perfection.

\subsubsection{The Notion of Perfect Human Being in Islam}

The notion of a perfect, universal human being was initially introduced by Muslim scholars Ibn Sina and Ibn Tufayl.[41] Ibn Arabi developed this notion further and used it in a systematic way. According to Ibn Arabi the first human, Adam is the first perfect man rather than being the first sinner.[42] He explains three main concepts within the frame work of a perfect man: God's names and attributes are reflected best on man, so human beings can represent all the names and attributes of God in the human dimension (maqamjam'i); there are certain weaknesses and contradictions in the nature of mankind but he/she is still capable of knowing God best with his/her capacity (maqambarzahiyyat); and mankind is a moral being who can act according to his/her knowledge and responsibility (maqamkhilafat).[43]

Ibn Arabi holds that maqamjam ' $i$ (the state of combining) is the highest capacity in regard to manifesting the names and attributes of God; therefore, mankind is the only being who reflects all the names and attributes of God in the best way possible.[44] Perfect human being (insan al-kāmil) is the highest level in the hierarchy of creation. He explains the statement of 'God created Adam in His image'[45] as describing the concept of the perfect human being. He holds that the Divine Name "Allah" includes all other names of God and similarly the first man, Adam, contains all the names of God, so Adam is the summary of the whole universe.[46] Ibn Arabi's theory is further developed by his disciple Abdul Karim ibn Ibrahim al-Jîlî and is turned into a metaphysical thesis.[47]The perfect human being combines thought and action, words and intellect, says what he/she does, does what he/she says, feels what he/she thinks and thinks what he/she feels.[48] In the notion of perfect human being, the universe has not reached its perfect stage and it has not lost its progressive capacity.[49]The ego of mankind has great responsibility to contribute to the creation. At the turn of the twentieth century (1908) the great Pakistani- Indian thinker and philosopher, Muhammad Iqbal severely criticized the notion of pantheism and instead he emphasize on the human ego. For him, the real identity is not a "thing"; rather it is deed and action.[50]

\subsubsection{Worldly-other Worldly in Islam}

In the Islamic view, material is deemed as a means to achieve noble goals. This world is not Satan's property and the body is surely not his home. Even the Hereafter which is the place of ultimate hope or loss is described by God with worldly figures.[51] Islam introduces this world with its three aspects and Said Nursi explains it as follows:

"The world has three facets or aspects. The first facet is concerned with Almighty God's Names and shows their inscriptions and activity; it mirrors them. This facet is the Eternally Besought's collection of innumerable "letters." Therefore it is extremely beautiful and worthy of love. The second facet relates to the Hereafter. It is the field to sow for the Hereafter, the tillage of Paradise, the flowerbed of Divine Mercy. Like the first one, it is beautiful and worthy of love. The third facet is a veil of heedlessness, a plaything for human fancy and desire. The Qur'an praises creation and attaches importance to it due to the first two facets of the world, but warns people against the third facet."'[52]

The Qur'ann never ignores this world or the one after, and its legislation intends to satisfy the needs of a human from both physical and metaphysical aspects. Recognizing human nature and setting the rules which cover both worlds makes Islam more suitable for the human nature. For Islam, all of our senses, organs, and faculties such as the heart, intellect, and spirit have unique duties and pleasures and God will reward all of them accordingly.[53] For example, in reward for the sincere love you feel for your spouse due to her (or his) delightful compassion, laudable virtues and good conduct, God will make her (or him) an immortal friend for you in the Abode of eternal happiness.[54]

Islam's view on sexual life is balanced and it is realistic rather than being idealistic. As evidenced in his life time, through the culture and discipline of his Sunnah -as documented in the Prophetic Traditions-, the Prophet rejected all kind of extreme approaches in worldly or 
spiritual matters and he set the middle way in every aspect of life. He was not against wealth but was against being a slave of wealth. Struggling for better standards in life and removing ignorance, poverty, illnesses, corruption and all kinds of negative conditions are deemed as part of moral and good character by the Prophet Muhammad. He knew that people cannot be saints or very pious individuals just by performing the prayers, fasting and doing devotional worship. It was exactly for these reasons that the first Muslims who were educated by the Prophet lived their human nature at the highest level within the boundaries of Islam. They never secluded themselves from society and ignored worldly matters, permissible foods, conducts and so on. They experienced real freedom by controlling their natural desires and utilizing them in a balanced way. They knew that this world was not permanent but they never ignored it by denouncing its necessities.

\section{Conclusion}

In the final analysis, human beings represent God's names and attributes in the human dimension and God manifests Himself best on the human soul, without becoming man himself. Every individual has a capacity to be the perfect human being. [55] From the first man, Adam- to the last and final Prophet, all were prototypes in regards to becoming the most polished mirrors to God and therefore all the names and attributes of God are manifested best on human beings.[56] Mankind does not, essentially represent or share the essential qualities of God which are related to His Essence, but they represent the names and attributes of God which are reflected in the creation of the universe and in their nature. However, they remain as human and they never share any divinity with God in His names, attributes and essential qualities.

God defined mankind in the Qur'ān with the names and attributes which are used for God Himself and encouraged human beings to represent the qualities of God in the human dimension. For example, by feeding the hungry, mankind represents the name of God Razzaq(the Sustainer, the Nourisher), by assuring others and providing them security a human being represents the name of God Mu'min (the Faithfull), and by showing mercy to other beings he represents the name Rahim (the Compassionate). The other names and attributes of God can be analyzed in this manner, so the strong connection between God and His servants may be seen more clearly.

The one who possesses these names and attributes in the absolute sense can really be appreciated by the one who has those names in a limited sense. A powerful man/woman really appreciates the Almighty God in the very moment he/she loses his/her power and becomes weak. The knowledgeable human being really appreciates the All-Knowing God in the moment they could not predict what will happen to them the next minute. As a result, all the names and attributes which we borrowed from God are a means to knowing God better, appreciating His works, contributing to the entire creation through them and recognizing his Lordship whilst at the same time acknowledging our bond of servitude.

In short, the identity of mankind or his/her ego should be understood from the view point of their vicegerency by representing the names and attributes of God on earth.

\section{REFERENCES}

[1] H. Richard Niebuhr, The Responsible Self, p. 48.

[2] W. D. Ros, "The Works of Aristotle,"EthicaNicomachea,Oxford Clarendan Press, 1925 Vol. 9, 1, 1.

[3] Fethullah Gulen, "HakKarşısındakiKonumuveDuruşuyla İnsan,”Sizintimagazine, Issues 182-183, 1994.

[4] Qur'ān 2: 30-34. Ali Unal,The Quran with Annotated Interpretation in Modern English, Light, New Jersey 2006

[5] The Protected Tablet or the metaphorical page of time along which God manifests or hangs whatever He wills and decrees of the beings and/or things and events recorded on the Supreme Ever-Preserved Tablet, where the Divine principles that determine the archetypal 'plan and program' of the creation and the future lives of all beings including all their deeds are kept recorded.

[6] Fethullah Gulen, Reflections on the Qur'ān,New Jersey: Tughra Books, 2012, p. 16.

[7] Gulen, ibid., p.16.

[8] Gulen, ibid.

[9] Wilhelm Keller,İnsan Doğası, (translated by Akın Kanat), İzmir: İlyaMatbaas1, second edition, 2001, p. 75.

[10] William Chittick, HayalÂlemleri İbn ArabîveDinlerinÇeşitlil iğiMeselesi, (translated by Mehmet Demirkaya), Istanbul: KaknüsYayınları, 1999, p. 55.

[11] Bryan Magee, Men of Ideas,New York: The Viking Press, 1979, p. 11.

[12] Arthur Schopenhauer, The World as Will and Representation, p. 445.

[13] David Hume, A Treatise of Human Nature,London: Penguin Books, 1984, pp. 310-311.

[14] Stanley Cavell, Must We Mean What We Say,New York: Charles Scribner's Sons, 1969, p. 67.

[15] Fethullah Gulen, Reflections on the Qur'ān, p.17.

[16] Gulen, ibid.

[17] Ken Wilber, The Integral Vision,Boston and London: Shambhala Publications, 2007, p. 31.

[18] Thomas Sheehan, Heidegger The Man and the Thinker, Chicago: Precedent Publishing, 1981, p. 7.

[19] Wilhelm Keller, Human Nature, p. 80. 
[20] Waulter Kaufmann, Discovering the Mind,New York: McGraw-Hill Book Company, 1980, p. 15.

[21] Keller, Human Nature, p. 81.

[22] Niebuhr, Christ and Culture, p. 41.

[23] Friedrich Nietzsche, The Will to Power, (translated by Walter Kaufmann), New York: Vintage Books 1968, p. 264.

[24] Niebuhr, Christ and Culture, p. 47.

[25] Nietzsche, The Will to Power, p. 333.

[26] Richard Rorty, Philosophy and the Mirror of Nature, Princeton University Pres. Princeton, New Jersey 1979 p. 27.

[27] Niebuhr, Christ and Culture, p. 42.

[28] Fritjof Kapra, Uncommon Wisdom, Published by Simon and Schuster, New York 1988, p. 98.

[29] Qur'ān 2: 10.

[30] Fethullah Gulen, Reflections on the Qur'ān, p. 5.

[31] Qur'ān 91: 7-8.

[32] Qur'ān 16: 78.

[33] Griffin, God and Religion in the Postmodern World, p. 14.

[34] Niebuhr, the Responsible Self, pp. 9-10.

[35] Niebuhr, ibid, pp.12-13.

[36] Niebuhr, the Nature and Destiny of Man, p. 136.

[37] Griffin, God and Religion in the Postmodern World, p. 15.

[38] Niebuhr, the Nature and Destiny of Man, p. 166.

[39] Man has an essential part in the universe, everything is created for human beings and the realities must be searched in their experiences.

[40] Griffin, God and Religion in the Postmodern World, p. 23.
[41] Ibn Tufayl, "Hayy the Son of Yaqzan", (translated by George N. Atiyeh), Canada: Medieval Political Philosophy: A Sourcebook, (ed. R. Lerner \& M. Mahdi), 1963, p. 134.

[42] Ibn Arabi,Kitabu'l-Isfar an-Nataiji'l-AsfarRasailuIbn Arabi, (ed. MuhammadShihabaddin al-Arabi), Beirut: Dar al-Sâdır, 1997, p. 472

[43] AbdulhamidSinanoğlu, İslâmDüşüncesinde "İnsan-1 kâmil" Anlayıșıve Allah ileİlişkilendirilmesininTeolojikDeğeri,Kelâ mAraştırmaları (Scholastic Theology Research Journal), 6: 2 (2008), pp. 93-114.

[44] Ebu'l-ÂlâAfîfî, Muhyiddin İbn Arabî'deTasavvufFelsefesi, (tr. Mehmet Dağ), Istanbul: KırkambarKitaplı̆̆ı, 1998, p. 97.

[45] Bukhari, Sabīb, Isti'zan, hadith no: 1.

[46] Ibn Arabi, Futuhat, vol.2 p. 121; vol. 13 pp. 125-131; Michel Chodkiewicz, SahilsizBirUmman Muhyiddin İbn Arabî, (trans.), Istanbul, 2003, pp. 59-61.

[47] JamilahKhatoon, “Iqbal's Perfect Man", Studies in Iqbal's Thought and Art, (ed. Saeed Sheikh), Lahore 1972, p. 125.

[48] Muhammad Iqbal, The Development of Metaphysics in Persia, London, 1908, pp. 172-174.

[49] Muhammad Iqbal, The Reconstruction of Religious Thought in Islam, London, 1934, p. 10.

[50] Ishrat Hasan, Metaphysics of Iqbal, Lahore, 1944, p. 31.

[51] Qur'ān 2: 25; 4: 13,57,122.

[52] Said Nursi, the Words, (trans.), New Jersey: Light Inc., New Jersey, 2010, p. 623.

[53] Nursi, ibid, p. 660.

[54] Nursi, ibid, p. 661.

[55] Ibn Arabi, Fusus al- Hikam, p. 56.

[56] Izutsu, İbn Arabî'ninFusûs'undakiAnahtarKavramlar, (trans.), Istanbul: KaknüsYayınları, 1998, p. 317. 